\title{
Library School Faculty Member Perceptions Regarding Faculty Status for Academic Librarians
}

\section{Paul Alan Wyss}

The faculties of the library schools listed as ALA-accredited are directly involved in setting the direction of the education provided to academic librarians through curriculum development and teaching. The curricula and teaching at ALA-accredited library schools revolve around aspects of librarianship such as providing research assistance at a reference desk, collection development, and cataloging; but they do not address preparing the recipients of the MLS for the demands of faculty status at a college or university library. Thus, while academic librarians may be well prepared to assume professional duties in an academic setting, they may be less well prepared to perform activities such as research and publication that are required of faculty members seeking tenure and promotion.

Until this descriptive study, the faculties of the ALA-accredited library schools had not been surveyed as a population in regard to their perceptions about faculty status for academic librarians, nor had they been surveyed about how education at library schools prepared academic librarians for faculty roles. As a result, it was vital that the faculties of the ALA-accredited library schools were surveyed so that their thoughts on faculty status for academic librarians and the education that prepares librarians for faculty roles could be known.

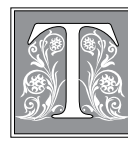

hroughout the twentieth century, librarians, teaching faculty, and administrators struggled with the question of faculty status for academic librarians. Although there has been much discussion on the issue, there has been no agreement as to whether academic librarians should be professional staff or members of the faculty. The importance of this study revolves around the issues of faculty roles for librarians within colleges and universities and also on the educational backgrounds that prepare them for such roles. Without an examination of how professors of librarianship view these issues, academic librarians are at risk of being placed in situations for which they are unprepared. This study also contributes to the literature on library science education and may impact the manner in which academic librarians

Paul Alan Wyss is Distance Learning Librarian at Minnesota State University Mankato;e-mail: paul.wyss@ mnsu.edu. This article is based on the author's dissertation research in Adult and Higher Education, directed by Karen Card, Ph.D., Division of Educational Administration, University of South Dakota. C Paul Alan Wyss 
develop their roles within colleges and universities.

\section{Review of Selected Literature}

A considerable amount of research has been published on the topic of faculty status for academic librarians. As early as 1878, Sawtelle saw the need for librarians to have faculty status since they facilitated the research of students and mentored them during academic endeavors. ${ }^{1}$ Later, Murray-Rust and Gorman viewed librarians with faculty status as being more highly valued in their institutions than their colleagues who did not have it. ${ }^{2}$ In opposing faculty status for librarians, Cronin and White saw it as not making a difference as far as users were concerned and that faculty roles did not fit the work schedules of librarians, leaving them with less unstructured time for research and publication. ${ }^{3}$ These opinions illustrate the conflicting views of librarians as faculty and have implications for the education they need to be prepared for the rigors of faculty roles.

The terminal degree requirement for academic librarians has also been a contentious issue within librarianship and the academy. Although the American Library Association has maintained that the MLS is the appropriate terminal professional degree for academic librarians, scholars such as Hérubel and Mayer and Terrill have disagreed with that position. ${ }^{4}$ In addition, Mayer and Terrill, Hérubel, Jones, and Axford have asserted that the coursework in MLS programs is not adequate for the scholarly pursuits of library faculty. ${ }^{5}$ These beliefs demonstrate that librarians and administrators have no firm guidelines on what are to be considered the proper academic credentials for faculty status librarians.

The education that librarians receive at library schools affects how successfully they execute their duties. This is of great importance, since the Association of College and Research Libraries has stated that librarians must be able to exercise independent judgment in the performance of professional duties and that their performance must be subject to regular and rigorous review. ${ }^{6}$ Library directors Galloway and Axford disagreed on the willingness of librarians to accept their responsibilities as librarians and faculty. Galloway stated that librarians did not shun their responsibilities and performed them fully even when they had faculty status. ${ }^{7}$ Axford, however, maintained that librarians were unwilling to accept scholarly activities as part of their professional responsibilities and, in fact, hoped to avoid them. ${ }^{8}$ In a related matter, Bentley and Ring documented that librarians with faculty appointments were not on equal footing with the teaching faculty where sabbatical and other research leaves were concerned, while Kenny discovered that, although release time for librarians had not been the norm, it was beneficial to librarians in their publishing endeavors. ${ }^{9}$ Thus, it would appear advantageous for faculty-status librarians to have the same opportunities for sabbaticals and release time as the teaching faculty if they are to meet the publication standards of their institutions.

Governance issues were prominent in the literature related to faculty status for academic librarians as well. Murray-Rust wrote that, in her experience, librarians who participated in campus governance were held in higher esteem by the greater academic community than those who did not. ${ }^{10}$ Herring, on the other hand, stated that participation in governance "provided a veneer of equality between the 'real professors' and library faculty."11 Involvement in governance provides faculty members with a voice in setting the priorities and directions of their institutions. A remark such as Herring's is potentially troubling to librarians with faculty status because it marginalizes the contributions they make to their campus communities.

Historically, librarians with faculty status have not been compensated on an equal level with the teaching faculty. This inequity has been consistent throughout 
recent decades. Bentley discovered that only 53.3 percent of librarians were on an academic year contract. ${ }^{12}$ Krompart and DiFelice, in a review of 10 library surveys, found that librarians' salaries were lower than those of the teaching faculty in at least 50 percent of the surveys. ${ }^{13}$ Remuneration, however, has been criticized as a justification for seeking faculty status. Dougherty wrote, "Is the goal of achieving faculty status worth the struggle? If a commitment to quality library services is the driving force, then I believe it is. But if the motives are rooted in desires to improve salaries and other perks, maybe it's time to rethink those motives, because there are easier and more humane ways to achieve better rewards than trying to convince faculty that we are like them."14

\section{Methodology Population}

To avoid any bias associated with a sample population, an entire population was surveyed in this study. The population consisted of the 906 tenure-track or tenured faculty members of the 57 ALAaccredited library schools as of April 2007. The list of ALA-accredited library schools was obtained from the ALA Web site. The list of the tenure-track or tenured faculty members of ALA-accredited library schools was obtained from each library school's Web site.

\section{Instrumentation}

The researcher created a Library School Faculty Member Perceptions Regarding Faculty Status for Academic Librarians Survey for the selected population. The Appendix of this article contains the text of the survey. A panel of librarians with faculty status at a Midwestern university critiqued the survey for clarity. The survey instrument was an e-survey using Zoomerang.

The Library School Faculty Member Perceptions Regarding Faculty Status for Academic Librarians Survey was designed to elicit responses that were scored on a five-point Likert scale corresponding with the statements of Strongly Disagree (1), Disagree (2), Neutral (3), Agree (4), and Strongly Agree (5). The Library School Faculty Member Perceptions Regarding Faculty Status for Academic Librarians Survey included 24 survey items.

\section{Research Questions}

This study addressed the following research questions:

1. What are the perceptions of the faculty members of ALA-accredited library schools regarding academic librarians having faculty status equivalent to that of the teaching faculty?

2. What is the difference in perceptions of the faculty members of ALAaccredited library schools regarding academic librarians having faculty status equivalent to that of teaching faculty based on the following personal characteristics:
a. Gender
b. Tenure status
c. Academic rank

3. What are the perceptions of the faculty members of ALA-accredited library schools regarding the adequacy of the library school curricula that prepare librarians for employment in academic libraries?

4. What are the perceptions of the faculty members of ALA-accredited library schools regarding the appropriate terminal degree(s) for academic librarians?

5. What are the perceptions of the faculty members of ALA-accredited library schools regarding how academic librarians should be evaluated?

6. What are the perceptions of the faculty members of ALA-accredited library schools regarding participation in library governance and college or university governance by academic librarians?

7. What are the perceptions of the faculty members of ALA-accredited library schools regarding compensation for academic librarians?

8. What are the perceptions of the faculty members of ALA-accredited library 
schools regarding sabbaticals and research release time for academic librarians?

\section{Data Collection}

A link to a Zoomerang version of ALAaccredited Library School Faculty Member Perceptions Regarding Faculty Status for Academic Librarians Survey along with a cover letter requesting participation was e-mailed to each member of the survey population. The cover letter provided information on the nature of the survey and the confidentiality of participant data. In addition, the cover letter included a request for the participants to complete the survey within 10 days of receipt. After the initial e-mailing of the cover letter and survey, a follow-up e-mail was sent to the survey population. Since Zoomerang versions of surveys do not ask for identifying data, anonymity of the individuals in the survey population was assured.

\section{Data Analysis}

The perceptions of the faculty members of ALA-accredited library schools for research question 1 , and research questions 3 through 8 , were determined by calculating the means and standard deviations for their respective survey questions. In analyzing research question 2 , the following inferential statistics were used: A $t$ test was used to determine if there were differences in ALA library school faculty members' perceptions (dependent variable) based on gender and tenure status (independent variables). A one-way analysis of variance (ANOVA) was used to determine if there were differences in ALA-accredited library school faculty members' perceptions (dependent variable) based on academic rank (independent variables). A .05 level of significance was used in the ANOVA. A post hoc Least Significant Difference test was also performed.

\section{Results}

Of the 906 individuals who were sent a link to the Library School Fac- ulty Member Perceptions Regarding Faculty Status for Academic Librarians Survey, there were 187 respondents. This equaled a response rate of 20.6 percent.

The majority $(60.0 \%)$ of ALA-accredited library school faculty members who responded to the survey were female; the majority $(65.0 \%)$ of the respondents were tenured; and, of the ALA-accredited library school faculty members who responded to the survey, 2.1 percent were lecturers, 33.7 percent were assistant professors, 25.7 percent were associate professors, and 38.5 percent were professors. These data are presented in table 1 .

The following section presents the results for the research questions regarding faculty status for academic librarians; perceptions on faculty status for academic librarians based on the gender, tenure status, and academic rank of respondents; the curricula that prepare librarians for employment in academic libraries; the terminal degree(s) for academic librarians; the manner in which faculty status librarians should be evaluated; participation in college or university governance by faculty status academic librarians; the compensation of faculty status academic librarians; and sabbaticals and research release time for academic librarians with faculty status.

\begin{tabular}{|l|c|c|}
\hline \multicolumn{3}{|c|}{ TABLE 1 } \\
Demographic Characteristics of \\
Respondents \\
\hline Characteristic & Frequency & Percent \\
\hline Gender & & \\
\hline Male & 75 & 40.0 \\
\hline Female & 111 & 60.0 \\
\hline Tenure Status & & \\
\hline Tenured & 117 & 65.0 \\
\hline Tenure-track & 63 & 35.0 \\
\hline Faculty Rank & & \\
\hline Lecturer & 4 & 2.1 \\
\hline Assistant Professor & 63 & 33.7 \\
\hline Associate Professor & 47 & 25.7 \\
\hline Professor & 72 & 38.5 \\
\hline
\end{tabular}


TABLE 2

Differences in Perceptions Based on Faculty Rank

\begin{tabular}{|l|c|c|c|c|c|}
\hline Survey Question & Assist. Prof $_{2,3}$ & Assoc. Prof $_{1,3}$ & Professors $_{1,2}$ & $\mathrm{~F}$ & $\mathrm{P}$ \\
\hline Equivalent Status & $\mathrm{M}=2.71$ & $\mathrm{M}=2.50$ & $\mathrm{M}=3.24$ & 4.75 & $.003^{*}$ \\
\hline
\end{tabular}

* denotes significant difference at .05

Findings are also provided for the research question related to how gender, tenure status, and academic rank influence the perceptions of ALA-accredited library school faculty members on faculty status for academic librarians. Respondents were asked to respond to survey statements using a five-point Likert scale ranging from Strongly Disagree (1), Disagree (2), Neutral (3), Agree (4), and Strongly Agree (5). In describing the data, 5.00 to 4.50 is equal to Strongly Agree, 4.49 to 3.50 is equal to Agree, 3.49 to 2.51 is equal to Neutral (neither agree nor disagree), 2.50 to 1.51 is equal to Disagree, and 1.50 to 1.0 is equal to Strongly Disagree. A cut point of 1.00 was used to describe variability, with standard deviations above 1.00 being indicative or wide or broad variability.

\section{Perceptions on Faculty Status for Academic Librarians}

Research question 1 assessed the perceptions of ALA-accredited library school faculty members on academic librarians having the same type of faculty status as the teaching faculty. Although spanning a broad range $(S D=1.30)$, respondents neither agreed nor disagreed with academic librarians having the same type of faculty status as the teaching faculty $(M=2.89)$.

\section{Perceptions on Faculty Status Based on Personal Characteristics}

Research question 2 assessed the perceptions of ALA-accredited library school faculty members on academic librarians having the same type of faculty status as the teaching faculty based on the personal characteristics of gender, tenure status, and faculty rank. There was no significant difference in library school faculty members perceptions based on gender or tenure status. However, there was a difference based on faculty rank. Professors' $(M=3.24)$ perceptions of faculty status for academic librarians were significantly more positive than those of assistant professors $(M=2.71)$ and associate professors $(M=2.50)$. These data are presented in table 2 .

\section{Perceptions on Curricula}

Research question 3 assessed the perceptions of ALA-accredited library school faculty members on the curricula preparing academic librarians for faculty status. Library school faculty members strongly agreed $(M=4.94)$, and with little variation $(S D=0.24)$, that courses in the essential elements of experimental and nonexperimental research should be required of students seeking a doctoral degree in Library Science. They also strongly agreed $(M=$ $4.88)$, and with little variation $(S D=0.43)$, with the requirement of courses that introduce statistical concepts and procedures to students seeking a doctoral degree in Library Science.

Library school faculty members agreed that courses in the essential elements of experimental and nonexperimental research should be required of students seeking a master's degree in Library Science $(M=4.02)$, although their perceptions spanned a broad range $(S D=$ 1.02). They also agreed that courses that introduce statistical concepts and procedures should be required of master's level students as well $(M=3.72)$, although their perceptions once again spanned a broad range $(S D=1.10)$. Library school faculty members disagreed that the MLS degree was sufficient to prepare librarians for faculty status $(M=2.26)$, while showing a broad variation $(S D=1.19)$ of perceptions on this issue as well. These data are presented in table 3 . 


\begin{tabular}{|l|c|c|}
\hline \multicolumn{3}{|c|}{ TABLE 3 } \\
\hline Perceptions on Curricula \\
\hline Survey Question & M & SD \\
\hline Research courses required of doctoral students & 4.94 & 0.24 \\
\hline Statistical courses required of doctoral students & 4.88 & 0.43 \\
\hline Research courses required of MLS students & 4.02 & 1.02 \\
\hline Statistical courses required of MLS students & 3.72 & 1.10 \\
\hline MLS is sufficient preparation for faculty status & 2.26 & 1.19 \\
\hline
\end{tabular}

MLS degree being recognized as the terminal degree for all academic librarians with faculty status $(M=2.74)$, although their perceptions showed broad variability $(S D=1.27)$. Library school faculty members disagreed with the MLS not being a requirement

\section{Perceptions on Academic Degrees}

Research question 4 assessed the perceptions of ALA-accredited library school faculty on graduate degrees for academic librarians with faculty status. Library school faculty members agreed that additional graduate degrees improved performance of faculty status academic librarians in discipline-specific positions $(M=4.00)$ despite showing a broad variability $(S D=1.10)$ of perceptions. They were neutral on the issue that additional graduate degrees improved performance in all library faculty positions $(M=3.48)$, although their perceptions spanned a broad range $(S D=1.19)$. Library school faculty members were undecided that the MLS degree should be supplemented with an additional master's degree $(M$ $=3.21)$, with their perceptions showing a broad range of variability $(S D=1.23)$. They were also undecided on the issue that the MLS degree should be supplemented with a doctoral degree $(M=$ $3.12)$, with their perceptions once again showing a broad range of variability $(S D=$ 1.30). In addition, they were neutral on the for employment as an academic librarian if one has a graduate degree $(M=$ 1.78) while displaying a broad range in perceptions $(S D=1.15)$. These data are presented in table 4 .

\section{Evaluation of Academic Librarians with Faculty Status}

Research question 5 assessed the perceptions of ALA-accredited library school faculty on the evaluation of academic librarians with faculty status. Library school faculty members were in agreement that academic librarians with faculty status are at a disadvantage in producing research because of the daily responsibilities related to their positions $(M=3.73)$ despite showing a broad variability $(S D$ $=1.26$ ) of perceptions. They had no consensus of opinion on academic librarians with faculty status being covered by the same tenure policy as teaching faculty $(M$ $=3.17$ ) despite showing a broad variability $(S D=1.42)$ of perceptions. While showing broad variation $(S D=1.38)$, library school faculty members were undecided on the issue of academic librarians with faculty

\begin{tabular}{|c|c|c|}
\hline \multicolumn{3}{|l|}{$\begin{array}{c}\text { TABLE } 4 \\
\text { Perceptions on Academic Degrees }\end{array}$} \\
\hline Survey Question & M & SD \\
\hline Additional graduate degrees improve performance in discipline-specific positions & 4.00 & 1.10 \\
\hline Additional graduate degrees improve performance in all positions & 3.48 & 1.19 \\
\hline The MLS degree should be supplemented with an additional master's degree & 3.21 & 1.23 \\
\hline The MLS degree should be supplemented with a doctoral degree & 3.12 & 1.30 \\
\hline MLS as terminal degree & 2.74 & 1.27 \\
\hline MLS not needed for employment & 1.78 & 1.15 \\
\hline
\end{tabular}




\begin{tabular}{|l|c|c|}
\hline \multicolumn{3}{|c|}{ TABLE 5 } \\
Evaluation of Academic Librarians with Faculty Status \\
\hline Survey Question & M & SD \\
\hline Disadvantaged in producing research because of daily responsibilities & 3.73 & 1.26 \\
\hline Covered by the same tenure policy & 3.17 & 1.42 \\
\hline Publication standards should be equal & 3.03 & 1.38 \\
\hline Same evaluation criteria as teaching faculty & 2.86 & 1.40 \\
\hline No doctoral requirement for promotion to full professor & 2.48 & 1.40 \\
\hline
\end{tabular}

status being held to the same publication standards as their teaching counterparts $(M=3.03)$. They were neutral on academic librarians with faculty status being evaluated using the same criteria as teaching faculty $(M=2.86)$ while displaying a broad range of perceptions $(S D=1.40)$. In addition, they were undecided on academic librarians with faculty status being eligible for promotion to full professor if they did not have doctoral degrees $(M=$ $2.48)$ with their perceptions spanning a broad range $(S D=1.40)$. These data are presented in table 5 .

\section{Governance}

Research question 6 assessed the perceptions of ALA-accredited library school faculty members on governance issues as they relate to academic librarians with faculty status. They agreed that academic librarians with faculty status should be involved in library governance $(M=$ $4.20)$ and did so with little variation $(S D$ $=0.90)$. They also agreed that academic librarians with faculty status should be involved in university governance $(M=$ 4.16) and did so with little variation $(S D$ $=0.90)$. They agreed that involvement in university governance improves the perception among the teaching faculty of academic librarians $(M=4.04)$ with broad variation $(S D=1.07)$. They agreed that library directors/deans should rely on faculty status academic librarians because of the expertise they bring to their positions $(M=3.58)$ with broad variation $(S D=1.30)$ in perceptions. These data are presented in table 6 .

\section{Compensation and Benefits}

Research question 7 assessed the perceptions of ALA-accredited library school faculty compensation and benefits for academic librarians with faculty appointments. Library school faculty members were undecided with respect to academic librarians with faculty status being compensated with the same salaries and fringe benefits as teaching faculty members of equivalent ranks $(M=3.40)$ despite showing a broad range of variation $(S D=$ 1.31 ) in perceptions.

\section{Sabbatical and Research Leaves}

Research question 8 assessed the perceptions of ALA-accredited library school faculty regarding sabbaticals and research

\begin{tabular}{|c|c|c|}
\hline \multicolumn{3}{|l|}{$\begin{array}{c}\text { TABLE } 6 \\
\text { Governance }\end{array}$} \\
\hline Survey Question & M & SD \\
\hline Librarians should be involved in library governance & 4.20 & 0.90 \\
\hline Librarians should be involved in university governance & 4.16 & 0.90 \\
\hline $\begin{array}{l}\text { Involvement in university governance improves perception among the } \\
\text { teaching faculty }\end{array}$ & 4.04 & 1.07 \\
\hline Faculty-status academic librarians consulted by library directors/deans & 3.58 & 1.30 \\
\hline
\end{tabular}


release time for academic librarians with faculty status. Library school faculty members were in agreement that sabbatical and research leaves facilitate research and improve publication rates among librarians with faculty positions $(M=4.08)$, although their perceptions spanned a broad range $(S D=1.03)$. They were also in agreement that faculty status academic librarians should be eligible for the same sabbatical and research leaves as teaching faculty $(M$ $=3.81$ ) while once again showing a broad range $(S D=1.23)$ of perceptions. These data are presented in table 7 .

\section{Discussion}

Granting librarians faculty status equivalent to that of the teaching faculty is a contentious issue. Researchers who favored faculty status for librarians cited the benefits of professional and personal respect accrued to the librarians themselves, and the better services they provided to the teaching faculty and the university community as a whole as a result of their faculty roles. ${ }^{15}$ Those who opposed equivalent faculty status for librarians did so on the grounds that librarians garner professional and personal respect by excelling at the services they provide to campus communities rather than by having faculty status. ${ }^{16}$ The faculty members of the ALA-accredited library schools supported neither side of the debate. This is not surprising, given the diversity of opinion on the matter and that colleges and universities have different roles for their librarians. Thus, the points of view of Murray-Rust, Gorman, Dougherty, Cronin, White, and Leonhardt appear to hold equal validity depending on institutional needs, traditions, and expectations.

\begin{tabular}{|l|c|c|}
\hline \multicolumn{3}{|c|}{ TABLE 7 } \\
Sabbatical and Research Leaves \\
\hline Survey Question & $\mathrm{M}$ & SD \\
\hline $\begin{array}{l}\text { Sabbatical and research leaves facilitate } \\
\text { research and improve publication rates }\end{array}$ & 4.08 & 1.03 \\
\hline $\begin{array}{l}\text { Eligibility for the same sabbatical and } \\
\text { research leaves as teaching faculty }\end{array}$ & 3.81 & 1.23 \\
\hline
\end{tabular}

The faculty members of ALA-accredited library schools did not agree that the MLS degree was sufficient preparation for librarians with faculty status and had no consensus on the MLS being regarded as a terminal degree. This runs contrary to the pronouncement of the Association of College and Research Libraries, a division of the American Library Association, that "The master's degree in library science from a library school program accredited by the American Library Association is the appropriate terminal professional degree for academic librarians." ${ }^{17}$ This disconnect is potentially troublesome to academic librarians. If there is no agreement among library school faculty on whether the MLS is a terminal degree, how can there be consensus in the profession of librarianship or in academia?

Concomitant with the issue of the MLS as a terminal degree is the role that additional graduate degrees play in librarianship. Hérubel and Mayer and Terrill supported the idea that additional graduate degrees improved the performance of academic librarians. ${ }^{18}$ Library school faculty members agreed in part with this point of view. They thought that the MLS should be supplemented with an additional graduate degree for discipline-specific positions (such as music librarian or business librarian). However, they were undecided whether additional graduate degrees improved performance in all library faculty positions. Accordingly, librarians seeking faculty appointments should be aware that an MLS alone is not always thought of as a sufficient credential for such positions. They should also prepare themselves for the fact that they might be required to earn an additional graduate degree to be eligible for tenure and promotion.

Mayer and Terrill expressed concern that academic libraries are recruiting individuals with PhDs (but no MLS degree) to librarianship, 
especially in upper-level administrative positions. ${ }^{19}$ Hérubel addressed this concern by stating that PhDs entering librarianship need to be acculturated to the profession through the education provided in master's programs in library and information science. ${ }^{20}$ With respect to this matter, library school faculty members firmly agreed that MLS needs to be a requirement for employment as an academic librarian regardless of whatever type of other graduate degree one holds. This is important, as Hérubel stated, for, without this experience, those holding only a discipline-specific PhD lack the "intellectual or theoretical basis from which to interact with the larger issues in academic librarianship." 21

The faculty members of ALA-accredited library schools strongly agreed that courses on statistics and research processes be required of doctoral and master's-level library science students. These processes, identified by Kenny, include defining a research problem, understanding research design, selecting a research design appropriate to a research problem, audience identification, writing and effectively editing scholarly publications, and the process of publishing. ${ }^{22}$ Currently, MLS programs do not stress these processes, which are essential in producing scholarly publications. Since scholarly publication is often a requirement for obtaining tenure in faculty positions, it is imperative that library science students are introduced to these processes, which are crucial to the production of research publications. Library school faculty members also agreed that librarians are disadvantaged in producing research because of their daily responsibilities, that sabbatical and research leaves facilitated research and improved publication rates among library faculty, and that faculty status academic librarians should be eligible for the same sabbatical and research leaves as teaching faculty. Consequently, college and university administrators should allow their library faculty the same opportuni- ties for sabbatical and research leaves that they give the teaching faculty.

Library school faculty members had no consensus on librarians with faculty status being eligible for promotion to full professor if they did not have doctoral degrees. Research by Park and Riggs has shown that 10 percent of doctoral granting, 21.1 percent of comprehensive, and 15.3 percent of liberal arts institutions required a doctorate for promotion to full professor. ${ }^{23}$ Therefore, academic librarians seeking the highest faculty rank should investigate the requirements of their institution and, if necessary, earn a doctoral degree.

Consistent with having no consensus on the issue of librarians with faculty status being eligible for promotion to full professor if they did not have doctoral degrees, the faculty members of ALA-accredited library schools had no consensus on faculty-status librarians being covered by the same tenure policy as teaching faculty. They were also undecided on evaluating them using the same criteria as teaching faculty, or on holding them to the same publication standards as their teaching counterparts. An explanation of this might be that, as Hill suggested, evaluation for tenure is difficult because an acquisitions librarian might be unable to provide suitable evaluation of the work in interlibrary loan and a reference librarian might not be able to assess adequately the work of a cataloger. ${ }^{24}$ One can infer from this that the duties of ALA-accredited library faculty differ substantially from that of the teaching faculty, and to evaluate them in the same manner may be inappropriate.

Gorman and Herring decried governance as an issue by which librarians could justify faculty status..$^{25}$ Still, Gorman agreed with Murray-Rust that increased campus visibility of library faculty improved their standing with their teaching faculty counterparts. ${ }^{26}$ Library school faculty members concurred with this point of view. In addition, they agreed that library faculty should be involved in library gov- 
ernance as well. This was in recognition of the fact that academic librarianship has become so complex that no library director/dean could have sufficient expertise in all areas of librarianship to exercise sound judgment throughout their broad range.

Finally, library school faculty members had no consensus regarding academic librarians with faculty status being compensated with the same salaries and fringe benefits as teaching faculty members of equivalent ranks. This is an interesting finding, since Applegate, Cary, and Sherby discovered that one of the most often cited reasons for faculty status for academic librarians was that it helped to provide equity of salary and benefits with the teaching faculty. ${ }^{27}$

\section{Recommendations}

Library school faculty members have a vested interest in the curricula of library schools and in the direction of librarianship itself. Thus, one must examine their perceptions with care and ask substantive questions related to their points of view. For example, one could ask the question, "While library school faculty members may be well qualified to state that they believe research methods courses should be required of doctoral and master's-level students, are they similarly well qualified on the issue of compensation for faculty status librarians?" Given this cautionary note, recommendations for practice and further study can be made.

\section{Recommendations for Practice}

The following recommendations for practice have been developed based on the findings of the study:

1. A librarian who is interested in seeking a faculty-status position should earn an additional graduate degree since such degrees are seen as valuable for disciplinespecific positions and since some colleges and universities require that academic librarians have doctoral degrees to be eligible for promotion to full professor.

2. ALA-accredited library schools should require that doctoral and master's- level students take courses in the essential elements of experimental and nonexperimental research.

3. ALA-accredited library schools should require that doctoral and master'slevel students take courses that introduce statistical concepts and procedures.

4. Faculty status academic librarians should be involved in college and university governance as well as library governance.

5. Librarians with faculty status should be eligible for the same sabbatical and research leaves as teaching faculty.

\section{Recommendations for Further Study}

Based on the findings of this study, the following recommendations for further research are suggested:

1. A qualitative study of this type should be performed to identify the reasons behind the perceptions that library school faculty members have on the issues surrounding faculty status for academic librarians.

2. A qualitative study should be performed to assess how faculty status affects the personal and professional lives of academic librarians.

3. Additional research should be conducted so that a greater understanding of the ways in which faculty status for academic librarians impacts academic librarians and the institutions of which they are a part.

\section{Conclusion}

Taken as a whole, ALA-accredited library school faculty members are essentially neutral regarding academic librarians having faculty status equivalent to that of the teaching faculty. That being said, they believed that faculty status academic librarians should be eligible for the same sabbatical and research leaves as teaching faculty, that they should be involved in library governance, and that involvement in university governance improves the perception among the teaching faculty of academic librarians. Faculty members of the ALA-accredited library schools also be- 
lieved that academic librarians with faculty status are at a disadvantage in producing research because of the daily responsibilities of their positions and that sabbatical and research leaves facilitate research and improve publication rates among academic librarians with faculty status.

While ALA-accredited library school faculty members neither agreed nor disagreed on the MLS degree being recognized as the terminal degree for all academic librarians with faculty status, they disagreed that the MLS degree was sufficient to prepare academic librarians for faculty status. Along with this, the ALA-accredited library school faculty members believed that courses in the essential elements of experimental and nonexperimental research and statistics be required of all doctoral and master's-level Library Science students. In addition, they agreed that additional graduate degrees improved performance of faculty-status academic librarians in discipline-specific positions, while they neither agreed nor disagreed that additional graduate degrees improved performance in all library faculty positions.

In the end, considering the nature of the debate, faculty status for academic librarians will likely remain a conundrum for which there is no all-encompassing answer. Still, there remains sound guidance on the issue for both academic librarians and administrators from Dougherty and Wyatt, who concluded that, for faculty status to be valid for academic librarians, they needed to perceive their goals and missions within the larger context of the university and beyond the space of the library. ${ }^{28}$ For those involved, this may be the soundest guidance of all.

\section{Notes}

1. H.A. Sawtelle, “The College Librarianship," Library Journal 3 (1878): 162.

2. Catherine Murray-Rust, "Should Librarians Get Tenure? Yes, It's Crucial to Their Jobs," Chronicle of Higher Education 52, no. 6 (2005): 10; Michael Gorman, "Do Librarians with Tenure Get More Respect?" American Libraries 34, no. 6 (2003): 70-72.

3. Blaise Cronin, "The Mother of All Myths," Library Journal 126, no. 3 (2001): 144; Herbert White, "Faculty Status for Academic Librarians: The Search for the Holy Grail," Library Journal 121, no. 19 (1996): 39-40.

4. Jean-Pierre V.M. Hérubel, “To 'Degree' or Not to ‘Degree': Academic Librarians and Subject Expertise," College \& Research Libraries News 7 (1991): 437; Jennifer Mayer and Lori Terrill, "Academic Librarians' Attitudes about Advanced-Subject Degrees," College \& Research Libraries 66, no. 1 (2005): 69.

5. Mayer and Terrill, "Academic Librarians' Attitudes," 69; Hérubel, “To 'Degree' or Not to 'Degree'," 437; William Jones, "The Education of Academic Librarians: How Many Degrees Are Enough? [reply to J.-P. V.M. Hérubel]," College \& Research Libraries News 9 (1991): 585; H. William Axford, "The Three Faces of Eve: Or the Identity of Academic Librarianship: A Symposium," Journal of Academic Librarianship 2, no. 6 (1977): 277.

6. American Library Association, "Standards for Faculty Status for College and University Librarians." Available online at www.ala.org/ala/acrl/acrlstandards/standardsfaculty.cfm. [Accessed 2 December 2007].

7. R. Dean Galloway, "The Three Faces of Axford: Or Blaming the Victim in Academia," Journal of Academic Librarianship 2, no. 6 (1977): 280.

8. Axford, "The Three Faces of Eve," 277.

9. Stella Bentley, "Collective Bargaining and Faculty Status," Journal of Academic

Librarianship 4, no. 2 (1978): 77; Daniel Ring, "Professional Development Leave as a Stepping Stone to Faculty Status," Journal of Academic Librarianship 4, no. 1 (1978): 19; Kathleen Kenny, "Increasing Scholarly Productivity among Library Faculty: Strategies for a Medium-Sized Library," Journal of Academic Librarianship 16, no. 5 (1990): 278.

10. Murray-Rust, "Should Librarians Get Tenure?" 10.

11. Mark Herring, "Do Librarians with Tenure Get More Respect?" American Libraries 34, no. 6 (2003): 72.

12. Bentley, "Collective Bargaining and Faculty Status," 77

13. Janet Krompart and Clara DiFelice, "A Review of Faculty Status Surveys, 1971-1984," 
Journal of Academic Librarianship 13, no. 1 (1987): 15.

14. Richard Dougherty, "Editorial: Faculty Status: Playing on a Tilted Field," Journal of Academic Librarianship 19, no. 2 (1993): 67.

15. Sawtelle, "The College Librarianship," 162; Murray-Rust, "Should Librarians Get Tenure?" 10; Gorman, "Do Librarians with Tenure Get More Respect?" 70-72; Dougherty, "Faculty Status," 67.

16. Cronin, "The Mother of All Myths," 144; White, "Faculty Status for Academic Librarians," 39-40; Thomas Leonhardt, "Faculty Status," Technicalities 24, no. 4 (2004): 5.

17. American Library Association, "Standards for Faculty Status."

18. Hérubel, "To 'Degree' or Not to 'Degree'," 437; Mayer and Terrill, "Academic Librarians' Attitudes about Advanced-Subject Degrees," 69.

19. Mayer and Terrill, "Academic Librarians' Attitudes about Advanced-Subject Degrees," 70.

20. Jean-Pierre V.M. Hérubel, "Doctoral Degrees and the Academic Librarian; or, 'Is There a

Doctor in the House?'” Indiana Libraries 25, no. 3 (2006): 43.

21. Ibid.

22. Kenny, "Increasing Scholarly Productivity among Library Faculty," 278.

23. Betsy Park and Robert Riggs, "Tenure and Promotion: A Study of Practices by Institutional Type," Journal of Academic Librarianship 19, no. 2 (1993): 73-74.

24. Janet Hill, "Wearing Our Own Clothes: Librarians as Faculty," Journal of Academic Librarianship 20, no. 2 (1994): 74.

25. Gorman, "Do Librarians with Tenure Get More Respect?" 72; Herring, "Do Librarians with Tenure Get More Respect?" 72.

26. Gorman, "Do Librarians with Tenure Get More Respect?" 72; Murray-Rust, "Should Librarians Get Tenure?" 10.

27. Rachel Applegate, "Deconstructing Faculty Status: Research and Assumptions," Journal of Academic Librarianship 19, no. 3 (1993): 160; Shannon Cary, "Faculty Rank, Status, and Tenure for Librarians," College and Research Libraries News 62, no. 5 (2001): 511; Louise Sherby, "Academic Librarian: Librarian or Faculty Member?" Journal of Academic Librarianship 4, no. 5 (1978): 380.

28. Dougherty, "Faculty Status," 67; James Wyatt, “Defining Academic Librarianship," Journal of Academic Librarianship 4, no. 3 (1978): 133.

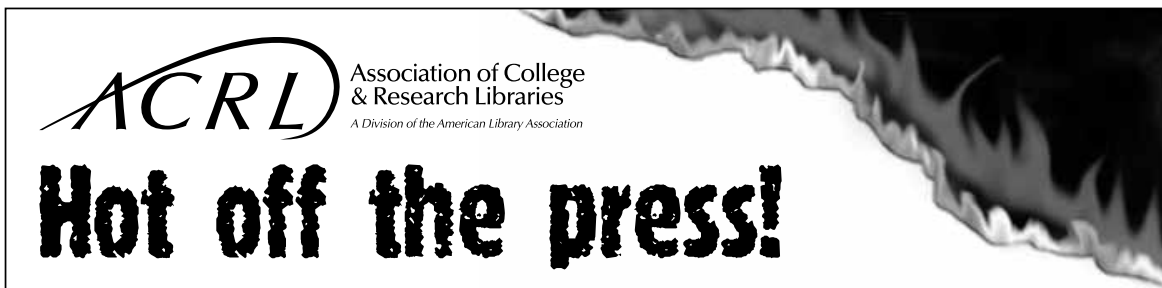

\section{Advocacy, Outreach and the Nation's} Academic Libraries: A Call for Action by William Welburn, Janice Welburn and Beth McNeil

This book provides a framework for opening dialogue and incorporating advocacy by exploring opportunities for advocacy and focusing on the world of civic engagement as well as the role of librarians as advocates on campus.
Comprehensive Guide to Emergency Preparedness and Disaster Recovery by Frances C. Wilkinson, Linda K. Lewis, and Nancy K. Dennis

Offers practical approaches on preparing for a disaster by creating a plan, responding to an emergency, and the intricacies of recovering from a disaster. Photographs, an extensive bibliography, glossary, model disaster preparedness plan, RFP model for selecting a disaster recovery vendor round out this volume.

\section{Visit the ALA online store for more information www.alastore.ala.org}




\section{Appendix}

\section{Library School Faculty Member Perceptions Regarding Faculty Status for Academic Librarians Survey}

The purpose of this study is to examine the perceptions of the tenure-track and tenured faculty members of the ALA-accredited library schools on faculty member status for academic librarians and on how the education at library schools prepares academic librarians for roles as faculty members.

On a scale of 1 to 5 (1-lowest [strongly disagree]; 5-highest [strongly agree]), please indicate the degree to which you disagree or agree with each of the following statements by culling the appropriate number.

\begin{tabular}{|l|l|c|c|c|c|c|}
\hline & \multicolumn{1}{|c|}{} & SD & D & N & A & SA \\
\hline 1. & $\begin{array}{l}\text { Academic librarians should have faculty status equiva- } \\
\text { lent to that of teaching faculty. }\end{array}$ & 1 & 2 & 3 & 4 & 5 \\
\hline 2. & $\begin{array}{l}\text { The MLS degree is sufficient to prepare librarians for } \\
\text { faculty status. }\end{array}$ & 1 & 2 & 3 & 4 & 5 \\
\hline 3. & $\begin{array}{l}\text { A course in the essential elements of experimental and } \\
\text { nonexperimental research studies should be required of } \\
\text { students seeking a MLS degree. }\end{array}$ & 1 & 2 & 3 & 4 & 5 \\
\hline 4. & $\begin{array}{l}\text { A course in the essential elements of experimental and } \\
\text { nonexperimental research studies should be required of } \\
\text { students seeking a doctoral degree in Library Science. }\end{array}$ & 1 & 2 & 3 & 4 & 5 \\
\hline 5. & $\begin{array}{l}\text { A course that introduces statistical concepts and pro- } \\
\text { cedures should be required of students seeking a MLS } \\
\text { degree. }\end{array}$ & 1 & 2 & 3 & 4 & 5 \\
\hline 6. & $\begin{array}{l}\text { A course that introduces statistical concepts and proce- } \\
\text { dures should be required of students seeking a doctoral } \\
\text { degree in Library Science. }\end{array}$ & 1 & 2 & 3 & 4 & 5 \\
\hline 7. & $\begin{array}{l}\text { The MLS degree is, and should be, the recognized termi- } \\
\text { nal degree for all academic librarians with faculty status. }\end{array}$ & 1 & 2 & 3 & 4 & 5 \\
\hline 8. & $\begin{array}{l}\text { The MLS degree should be supplemented with an ad- } \\
\text { ditional master's degree for academic librarians with } \\
\text { faculty status. }\end{array}$ & 1 & 2 & 3 & 4 & 5 \\
\hline 9. & $\begin{array}{l}\text { The MLS degree should be supplemented with a doctoral } \\
\text { degree in any academic discipline for academic librar- } \\
\text { ians with faculty status. }\end{array}$ & 1 & 2 & 3 & 4 & 5 \\
\hline 10. & $\begin{array}{l}\text { An additional graduate degree improves the performance } \\
\text { of academic librarians with faculty status for discipline- } \\
\text { specific positions (i.e., music librarian, business librarian). }\end{array}$ & 1 & 2 & 3 & 4 & 5 \\
\hline 11. & $\begin{array}{l}\text { An additional graduate degree improves the performance } \\
\text { of academic librarians with faculty status in all positions } \\
\text { (i.e., reference, cataloging, acquisitions). }\end{array}$ & 1 & 2 & 3 & 4 & 5 \\
\hline 12. & $\begin{array}{l}\text { The MLS does not need to be a requirement for employ- } \\
\text { ment as an academic librarian if one has a master's } \\
\text { degree or doctoral degree in an academic discipline. }\end{array}$ & 1 & 2 & 3 & 4 & 5 \\
\hline
\end{tabular}




\begin{tabular}{|c|l|c|c|c|c|c|}
\hline 13. & $\begin{array}{l}\text { Academic librarians with faculty status should be evalu- } \\
\text { ated using the same criteria as teaching faculty. }\end{array}$ & 2 & 3 & 4 & 5 \\
\hline 14. & $\begin{array}{l}\text { Academic librarians with faculty status should be cov- } \\
\text { ered by the same tenure policy as teaching faculty. }\end{array}$ & 1 & 2 & 3 & 4 & 5 \\
\hline 15. & $\begin{array}{l}\text { Academic librarians with faculty status but no doctoral } \\
\text { degree should be eligible for promotion to full professor. }\end{array}$ & 1 & 2 & 3 & 4 & 5 \\
\hline 16. & $\begin{array}{l}\text { Academic librarians with faculty status are at a disadvan- } \\
\text { tage in producing research because of the daily responsi- } \\
\text { bilities related to their positions. }\end{array}$ & 1 & 2 & 3 & 4 & 5 \\
\hline 17. & $\begin{array}{l}\text { Academic librarians with faculty status should be held } \\
\text { to the same publication standards as their teaching } \\
\text { counterparts. }\end{array}$ & 1 & 2 & 3 & 4 & 5 \\
\hline 18. & $\begin{array}{l}\text { Academic librarians with faculty status should be in- } \\
\text { volved in library governance. }\end{array}$ & 1 & 2 & 3 & 4 & 5 \\
\hline 19. & $\begin{array}{l}\text { In matters of library governance, faculty-status academic } \\
\text { librarians should be relied on by library directors/deans } \\
\text { because no director/dean has broad enough knowledge to } \\
\text { make sound decisions in all areas of librarianship. }\end{array}$ & 1 & 2 & 3 & 4 & 5 \\
\hline 20 & $\begin{array}{l}\text { Academic librarians with faculty status should be in- } \\
\text { volved in university governance. }\end{array}$ & 1 & 2 & 3 & 4 & 5 \\
\hline 21. & $\begin{array}{l}\text { Involvement in university governance improves the } \\
\text { perception among the teaching faculty of academic } \\
\text { librarians as professionals and colleagues. }\end{array}$ & 1 & 2 & 3 & 4 & 5 \\
\hline 22. & $\begin{array}{l}\text { Academic librarians with faculty status should be com- } \\
\text { pensated with the same salaries and fringe benefits as } \\
\text { teaching faculty members of equivalent ranks. }\end{array}$ & 1 & 2 & 3 & 4 & 5 \\
\hline 23. & $\begin{array}{l}\text { Academic librarians with faculty status should be } \\
\text { eligible for sabbatical and research leaves in the same } \\
\text { manner as teaching faculty. }\end{array}$ & 1 & 2 & 3 & 4 & 5 \\
\hline 24. & $\begin{array}{l}\text { Sabbatical and research leaves facilitate research and } \\
\text { improve publication rates among library faculty. }\end{array}$ & 1 & 2 & 3 & 4 & 5 \\
\hline
\end{tabular}

Thank you for completing this survey. For the purpose of data analysis of the survey responses, please provide the following information:

$\square$ Male $\square$ Female

$\square$ Tenured $\square$ Tenure-track

$\square$ Instructor/Lecturer $\square$ Assistant Professor $\square$ Associate Professor $\square$ Professor 


\section{"An investment in Knowledge pays the best interest."}

- Benjamin Franklin

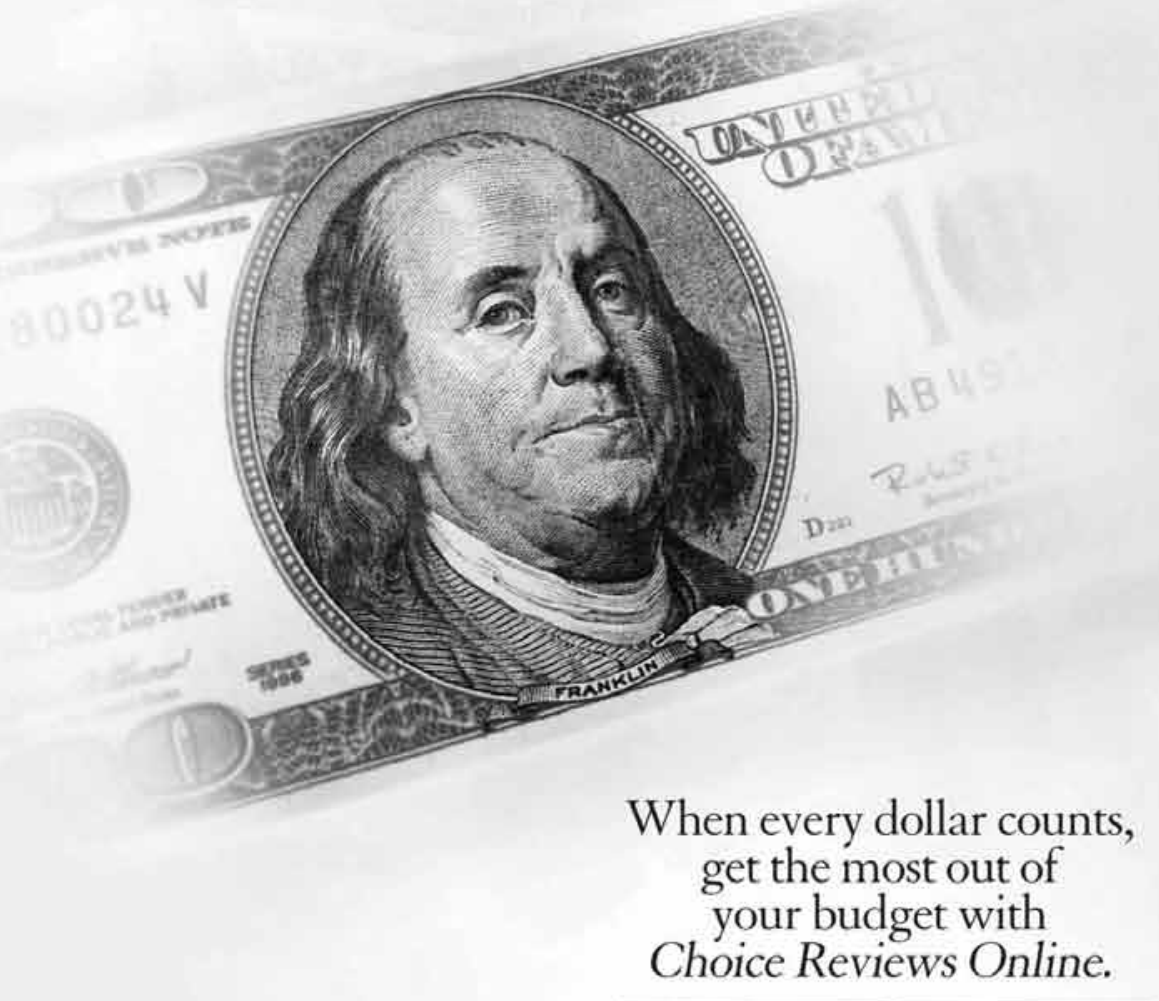

The perfect companion to a CHOICE print subscription:

- Access to over 145,000 CHOICE reviews

- Download, print or e-mail search results

- Ability to create a customized profile

- Create, save and e-mail lists

- Search all CHOICE content

- View exclusive online material

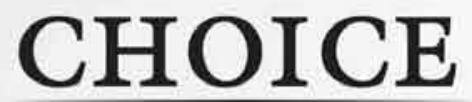

R E V I E W S O N L I N E

Choice is now on Facebook! Become a fan now by searching Choice Reviews Online on your Facebook page.

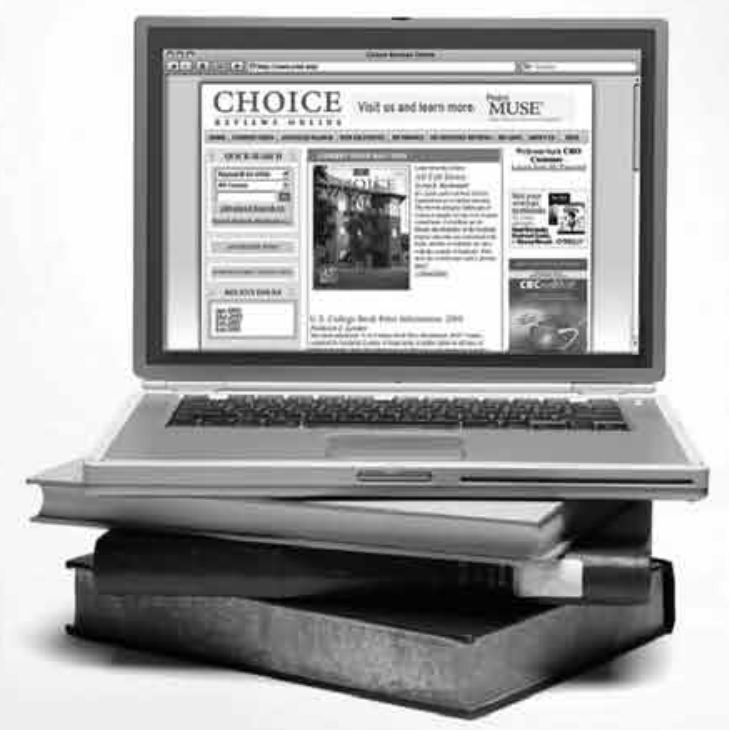

